\title{
PREVALENCE OF METABOLIC SYNDROME IN ACUTE MYOCARDIAL INFARCTION PATIENTS IN A TERTIARY CARE HOSPITAL IN CHENNAI
}

\author{
N. Senthil1 ${ }^{1}$, S. R. Ramakrishnan ${ }^{2}$, C. G. Sridhar ${ }^{3}$, J. Damodharan ${ }^{4}$ \\ ${ }^{1}$ Associate Professor, Department of General Medicine, Sri Ramachandra Medical College. \\ ${ }^{2}$ Associate Professor, Department of General Medicine, Sri Ramachandra Medical College. \\ ${ }^{3}$ Resident, Department of General Medicine, Sri Ramachandra Medical College. \\ ${ }^{4}$ Professor, Department of General Medicine, Sri Ramachandra Medical College.
}

\begin{abstract}
OBJECTIVES: To ascertain the prevalence of metabolic syndrome (MS) and to assess the association between the metabolic syndrome and its individual components- fasting blood sugar (FBS), blood pressure (BP), HDL cholesterol (HDL-C), triglyceride (TGL) and waist circumference(WC) and the frequency of its definitive components in patients with acute myocardial infarction. (AMI)

MATERIALS AND METHODS: This is a hospital based cross sectional study were 100 unselected patients with AMI categorized according to NCEP: ATP III 2001 CRITERIA were studied.

STATISTICAL ANALYSIS: Data was analyzed using the student's t test and chi-square test.

RESULTS: This study shows high prevalence of metabolic syndrome (53\%) in patients with AMI. Hypertension (85\%), Hyperglycemia (72\%) and Dyslipidemia (70\%) were found to be the most prevalent components of metabolic syndrome.

CONCLUSION: This study shows that there is a strong correlation between metabolic syndrome and AMI with Hypertension followed by Hyperglycemia having the highest positive predictive value among its components.
\end{abstract}

KEYWORDS: Metabolic Syndrome, Acute Myocardial Infarction, Cardiovascular Diseases.

HOW TO CITE THIS ARTICLE: N. Senthil, S. R. Ramakrishnan, C. G. Sridhar, J. Damodharan. "Prevalence of Metabolic Syndrome in Acute Myocardial Infarction Patients in a Tertiary Care Hospital in Chennai". Journal of Evolution of Medical and Dental Sciences 2015; Vol. 4, Issue 89, November 05; Page: 15397-15406, DOI: 10.14260/jemds/2015/2195.

INTRODUCTION: The metabolic syndrome (MS) is a combination of interrelated metabolic abnormalities that significantly increase the risk of cardiovascular disease, and type 2 diabetes mellitus (DM). ${ }^{1-6}$ its prevalence is increasing worldwide and is a serious public health problem. Each component of MS is individually associated with an increased risk of cardiovascular disease; however, whether MS leads to greater cardiovascular risk than the sum of its components remains a matter of debate. ${ }^{7}$ It has been suggested that the number of MS components may be more useful in predicting cardiovascular disease than MS itself, ${ }^{8}$ since cardiovascular risk increases as the number of components increases. ${ }^{9-11}$ similarly, given the heterogeneity of MS, the impact of the possible combinations of its components on predicting cardiovascular risk has been investigated. In this sense, DM is the predominant risk factor associated with the development of ischemic heart disease. 7,12

Some studies have analyzed the prevalence of MS in patients with acute coronary disease, reporting an estimated prevalence of $41 \%-50 \%$ in Europe and the United States. ${ }^{8,13}$

Financial or Other, Competing Interest: None.

Submission 10-10-2015, Peer Review 11-10-2015,

Acceptance 21-10-2015, Published 03-11-2015.

Corresponding Author:

Dr. N. Senthil,

No. 46, $7^{\text {th }}$ Street Kesari Nagar,

Adambakkam, Chennai-600088.

E-mail: sensuch74@yahoo.co.in

DOI:10.14260/jemds/2015/2195.
The definition of MS provided by the National Cholesterol Education Program-Adult Treatment Panel III (ATPIII) includes individuals with DM. It is known that DM strongly increases the risk of cardiovascular disease, and in fact is considered equivalent to having suffered a coronary event in terms of cardiovascular risk.14,15 Indians three times higher risk of developing Coronary Artery Disease (CAD) compared to Chinese and are 20 times more likely to die due to CAD compared to native black or white South Africans. ${ }^{16,17}$

The SHARE study demonstrated that South Asians had higher prevalence of cardiovascular disease compared to Europeans and Chinese living in Canada. ${ }^{18}$ In India 2.78 million deaths are due to cardiovascular diseases, of which over $50 \%$ is due to $\mathrm{CAD}$, making CAD the number one killer disease in our country. ${ }^{19}$ In Jaipur Heart Watch - 2 study conducted in 2002, prevalence of CAD was reported to be $8.2 \%{ }^{20}$ Over 35 million diabetic patients live in India, making India the diabetic capital in the world. These numbers expected to double by the year 2030.21 Thus India faces the dangerous dual epidemic of diabetes and CAD. The major root of both epidemics lies in "Metabolic Syndrome". (MS)

Individuals with MS have two times higher risk for mortality due to myocardial infarction or stroke and three times as likely to develop, myocardial infarction compared to people without MS.22

The relation of insulin resistance to cardiovascular risk, particularly CAD has been well established in many prospective studies in the West. In 1209 Finnish men aged 42- 60years, the 10-year CVD risk was increased 2.1 fold with the ATP III. ${ }^{23}$

The same study found that the risk of death from CVD was increased by 2.63-2.96 times and the risk of death from any 
cause was increased 1.87-2.11 times with the presence of the MS. The MS alone predicted $\sim 25 \%$ of all new-onset CVD. ${ }^{23}$ The DECODE study reported that the presence of MS increased all-cause and CVD mortality by 1.2-2.8 times. ${ }^{24}$ In the WOSCOPS (West of Scotland Coronary Prevention Study), MS defined by ATP III definition was associated with1.8-fold increase in CHD risk.

The aim of the present study was to determine the prevalence of MS and the frequency of its definitive components in patients with acute myocardial infarction in Sri Ramachandra Medical Centre a tertiary care medical college hospital in Chennai. Metabolic syndrome was diagnosed by using NCEP ATP III criteria.

MATERIALS AND METHODS: This hospital based crosssectional study was done in Department of Medicine, SRMC. 100 consecutive patients admitted with acute myocardial infarction diagnosed as per WHO criteria were included in the study.

All patients were thoroughly evaluated with a detailed history and appropriate investigations were done. Metabolic syndrome in subjects was diagnosed as per NCEP: ATP III 2001 criteria. Blood samples for fasting blood glucose were taken after eight hours of overnight fasting, $48 \mathrm{hrs}$. after hospital admission. Blood samples for lipid profile were taken the following morning (Within $24 \mathrm{hrs}$. of admission).

When assessing lipid profile, falsely low HDL concentrations may be observed in the presence of acutephase reactants, as may occur after an ACS. In order to mitigate this effect, blood samples were extracted within the first 24 hours after the cardiovascular episode if no blood test had been performed previously, since decreased HDL and triglyceride levels are of little relevance during this period. 25,26

Patient were diagnosed as metabolic syndrome if they have three of the following five NCEP: ATP III 2001 criteria; abdominal obesity (Waist circumference $>102 \mathrm{~cm}$ in male and $>88 \mathrm{~cm}$ in female), high triglyceride levels $(>150 \mathrm{mg} / \mathrm{dl})$, low HDL-C levels $(<40 \mathrm{mg} / \mathrm{dl}$ in male and $<50 \mathrm{mg} / \mathrm{dl}$ in female), elevated fasting blood glucose $(>110 \mathrm{mg} / \mathrm{dl})$ and high blood pressure (Systolic/diastolic blood pressure $>130 / 85$ ). Data were analyzed and interpreted using the student's t test and the chi-square test.

\section{DISCUSSION:}

Baseline Characteristics: Total of 100 patients with acute coronary syndrome was studied. 70 patients were males and 30 patients were females. Age groups were near normally distributed with sample mean being 57.10 years.

Maximum number of patients (53\%) was in the age group 40 to 60 years. The youngest patient being 32 years and oldest being 85 years. Mean age of females being 60.16 and mean age for males is 55.78 .

\section{CONCLUSION:}

- The present study shows a high prevalence of MS (53\%) in patients with acute myocardial infarction, with higher prevalence among males (62.3\%) than females (37.7\%).
- The most prevalent components of the MS were hypertension; hyperglycemia and dyslipidemia. Among the individual components of metabolic syndrome, it is observed in this study that the decreasing order of prevalence is Hypertension 85\%, impaired fasting Glucose/Diabetes 72\%, Dyslipidemia-(high TGL- 70\% and low HDL $-66 \%$ ) and increased waist circumference $42 \%$.

- As the prevalence of metabolic syndrome is already high and increasing exponentially due to sedentary life styles a preventive strategy is urgent need of the hour for our country which is facing a twin epidemic of diabetes and coronary artery disease.

\section{BIBLIOGRAPHY:}

1. Laaksonen De, LakkaHm, NiskanenLk, Kaplan Ga, SalonenJt, Lakka Ta. Metabolic Syndrome and Development of Diabetes Mellitus: Application and Validation of Recently Suggested Definitions of the Metabolic Syndrome in A Prospective Cohort Study.am J Epidemiol. 2002; 156:1070-7.

2. Grundy Sm, Cleemanji, Daniels Sr, Donatoka, Eckel Rh, Franklin Ba, Et Al. diagnosis And Management Of The Metabolic Syndrome: An American Heart Association/national Heart, Lung, And Blood Institute Scientific Statement. Circulation. 2005; 112:2735-52.

3. Hanley Aj, Festa A, D'agostinojrrb, wagenknecht Le, Savage $\mathrm{Pj}$, Tracy Rp, Et Al. metabolic And Inflammation Variable Clusters and Prediction of Type 2 Diabetes: factor Analysis Using Directly Measured Insulin Sensitivity. Diabetes. 2004; 53:1773-81.

4. Lindsay Rs, Howard Bv. Cardiovascular Risk Associated With the Metabolic Syndrome.currdiab Rep. 2004; 4:63-8.

5. Stern Mp, Williams K, Gonza ' Lez-villalpando C, Hunt Kj, Haffner Sm. Does The Metabolic Syndrome Improve Identification Of Individuals At Risk of Type 2 Diabetes And/or Cardiovascular Disease? diabetes Care. 2004; 27:2676-81.

6. Alberti Kg, Zimmet P, Shaw J. The Metabolic Syndrome: A New Worldwide Definition. Lancet. 2005; 366:1059-62.

7. Mente A, Yusuf S, Islam S, Mcqueenmj, Tanomsup S, Onencl, Et Al. Metabolic Syndrome And Risk Of Acute Myocardial Infarction. A Case-control Study of 26, 903 Subjects From 52 Countries. J Am CollCardiol. 2010; 55:2390-8

8. Solymossbc, Bourassa Mg, Campeau L, Sniderman A, Marcil M, Lespe ' Rancej, et Al. Effect Of Increasing Metabolic Syndrome Score On Atherosclerotic Risk Profile And Coronary Artery Disease Angiographic Severity. Am J Cardiol. 2004; 93:159-64.

9. Lakkahm, Laaksonen De, Lakka Ta, Niskanenlk, Kumpusalo E, Tuomilehto J, Et Al. Themetabolic Syndrome And Total And Cardiovascular Diseasemortality In Middle-aged Men. JAMA. 2002; 288:2709-16.

10. Sattar N, Gaw A, Scherbakova O, Ford I, O'reilly D, Haffnersm, Et Al. Metabolic Syndrome With And Without Creactive Protein As A Predictor Of Coronary Heart Disease And Diabetes In The West Of Scotland Coronary Prevention Study. Circulation. 2003; 108:414-9. 
11. Malik S,wongnd, Franklin Ss, Kamathtv, L'italiengj, Piojr, Et Al. Impact Of The Metabolic Syndrome On Mortality From Coronary Heart Disease, Cardiovascular Disease, And All Causes In United States Adults. Circulation. 2004; 110:1245-50.

12. Stamler J, Vaccaro O, Neatonjd, wentworth D. Diabetes, Other Risk Factors, And 12-yr Cardiovascular Mortality For Men Screened In The Multiple Risk Factor Intervention Trial.Diabetes Care. 1993; 16:434-44.

13. Chung Eh, Curran Pj, Sivasankaran S, ChauhanMs, Gossman De, Pyne Ct, Et Al.prevalence Of Metabolic Syndrome In Patients 45 Years of Age With Acute Myocardial Infarction Having Percutaneous Coronary Intervention.AMJCardiol. 2007; 100:1052-5.

14. Haffnersm, Lehto S, Et Al Mortality From Coronary Heart Disease In Subjects With Type 2 Diabetes And In Nondiabetic Subjects With And Without Prior Myocardial Infarction. N Engl J Med. 1998; 339:229-34.

15. Saydahsh, EberhardtMs, Loria Cm, Brancati Fl. Age and the Burden of Death Attributable To Diabetes In The United States. Am J Epidemiol.2002; 156:714-9.

16. Balarajan R. Ethnic Differences In Mortality From Ischemic Heart Disease And Cerebrovascular Disease In England And Wales.bmj 1991; 302: 560-4

17. Mckeigue Pm, Miller Gj, Marmot Mg. Coronary Heart Disease in South Asians Overseas: A Review. J Clinepidemiol 1989; 42: 597-609.

18. Anandss, Yusuf S, Vuksan V, Et Al. Differences In Risk Factors, Atherosclerosis, And Cardiovascular Disease Between Ethnic Groups In Canada: The Study Of Health Assessment And Risk In Ethnic Groups (share). Lancet 2000; 356: 279-84.

19. World Health Organization. The World Health Report 2002: Reducing Risks And Promoting Healthy Live. Geneva: Who; 2002.

20. Gupta R, Gupta Vp, Sarna M, Et Al. Prevalence Of Coronary Heart Disease And Risk Factors In An Urban Indian Population: Jaipur Heart Watch-2. Indian Heart J 2002; 54: 59-66.

21. Wild S, Roglic G, Green A, Sicree R, King H. Global Prevalence Of Diabetes, Estimates For The Year 2000 And Projections For 2030.

22. Stern Mp, Williams K, Gonzalez-villalpando C, Hunt Kj, Haffner Sm. Does The Metabolic Syndrome Improve Identification Of Individuals At Risk Of Type 2 Diabetes And/or Cardiovascular Disease? Diabetes Care 2004; 27: 2676-81.

23. Lakkahm, Laaksonen De, Lakka Ta, Niskanenlk, Kumpusalo E, Tuomilehto J, Salonenjt: The Metabolic Syndrome And Total And Cardiovascular Disease Mortality In Middle Aged Men. JAMA 2002; 288: 270916.
24. Hu G, Qiao Q, Tuomilehto J, Balkau B, Borch-johnson K, Pyorala K. Decode Study Group, Prevalence Of The Metabolic Syndrome And Its Relation To All-cause And Cardiovascular Mortality Innondiabetic European Men And Women. Arch Intern Med 2004; 164: 1066-76.

25. Ahnve S, Angelin B, Edhag O, Berglund L. Early Determination of Serum Lipids And Apolipoproteins In Acute Myocardial Infarction: Possibility For Immediate Intervention. J Intern Med. 1989; 226:297-301.

26. Henkin Y, Crystal E, Goldberg Y, Friger M, Lorber J, Zuili I, Et Al. Usefulness of Lipoprotein Changes During Acute Coronary Syndromes For Predicting Post-discharge Lipoprotein Levels. Am J Cardiol. 2002;89:7-11.

27. Ramachandran A, Snehalatha C, Satyavani K, Et Al. Metabolic Syndrome In Urban Asian Indian Adults: A Population Study Using Modified Atp Iii Criteria. Diabetes Res Clinpract 2003; 60: 199-204.

28. Deepa M, Farooq S, Datta M, Deepa R, Mohan V. Prevalence Of Metabolic Syndrome Using Who, Atp Iii And Idf Definitions In Asian Indians: The Chennai Urban Rural Epidemiology Study (cures-34). Diabetes Metab Res Rev 2006 Jun 5.

29. Kim Jy, Munhs, Lee Bk, Yoon Sb, Choi Ey, Min Pk, Et Al. Impact of Metabolic Syndrome And Its Individual Components On The Presence And Severity Of Angiographic Coronary Artery Disease. Yonsei Med J. 2010; 51:676-82.

30. Ana Jover Et Al. Prevalence of Metabolic Syndrome and Its Components in Patients with Acutecoronary Syndrome. Rev Esp. Cardiol. 2011; 64(7):579-586.

31. Stern Mp, Williams K, Gonzalez-villalpando C, Hunt $\mathrm{Kj}$, Haffner Sm. Does The Metabolic Syndrome Improve Identification Of Individuals At Risk Of Type 2 Diabetes And/or Cardiovascular Disease? Diabetes Care 2004; 27: 2676-81.

32. John E Morley Aging and Metabolic Syndrome. Neurobiology of Aging.vol.9, 1989, 9-16.

33. Melissari M Balbi, T. gennar M Olivetti. The Aging of Heart: Weight and Structural Changes In The Left Ventricle With Age. Cardial 1991,122-23

34. S. Pandey Et Al Prevalence of the Metabolic Syndrome in Acute Myocardial Infarction and Its Impact on Hospital Outcomes. International Journal OfDiabetology in Developing Countries. vol 29.2009 52-55.

35. Benghazi, I Et Al.-libya - A Pilot Study- Libyan I Med Acp: 080175.metabolic Syndrome In Type 2 Diabetes In Libya

36. Kjeldson Et Al; Increased Prevalence Of Metabolic Syndrome In Uncontrolled Hypertension Across Europe. Journal of Hypertension, 1213-1221.

37. Mathew S. Freiberg Md Et Al "Alcohol Consumption and Prevalence of Metabolic Syndrome in U.s ".Diabetes Care: 2054-2059, 2004. 


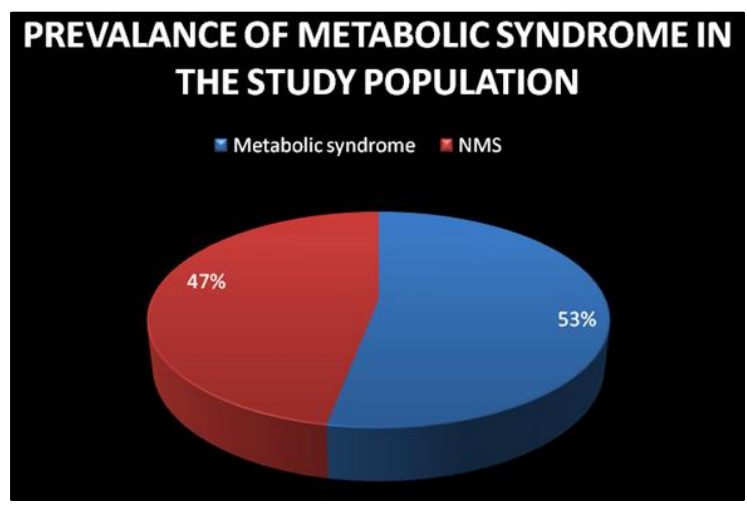

Fig. 1

\begin{tabular}{|c|c|}
\hline & Cases \\
\hline Metabolic Syndrome & 53 \\
\hline $\begin{array}{c}\text { NMS (Non-metabolic } \\
\text { syndrome) }\end{array}$ & 47 \\
\hline $\begin{array}{c}\text { Table 1: Prevalance of Metabolic Syndrome } \\
\text { in the Study Population }\end{array}$ \\
\hline
\end{tabular}

\section{PREVALENCE OF INDIVIDUAL RISK FACTORS IN METABOLIC} SYNDROME

\section{(Figure 2, Table 2)}

Among the individual components of metabolic syndrome, it is observed in this study that the decreasing order of prevalence is Hypertension 85\%, impaired fasting Glucose/diabetes 72\%, dyslipidemia-(High TGL- 70\% and low HDL $-66 \%$ ) and increased waist circumference $42 \%$ in a total of 53 metabolic syndrome cases. (Figure 2, Table 2).

The observation is similar to studies by Kim et al. ${ }^{29}$ and Ana Jover et al. ${ }^{30}$ where it showed the hyperglycemia and low HDL levels were the most prevalent components of MS, followed by hypertension in both the cohorts. MS increases cardiovascular risk and each of its components is associated with an increased risk of cardiovascular disease. Recent studies have shown that MS does not increase cardiovascular risk more than the sum of its components. Some works have suggested that the number of markers of MS can be more useful then MS itself in predicting cardiovascular disease, and that the risk of cardiovascular disease increases as the number of MS components increases. ${ }^{10,11}$

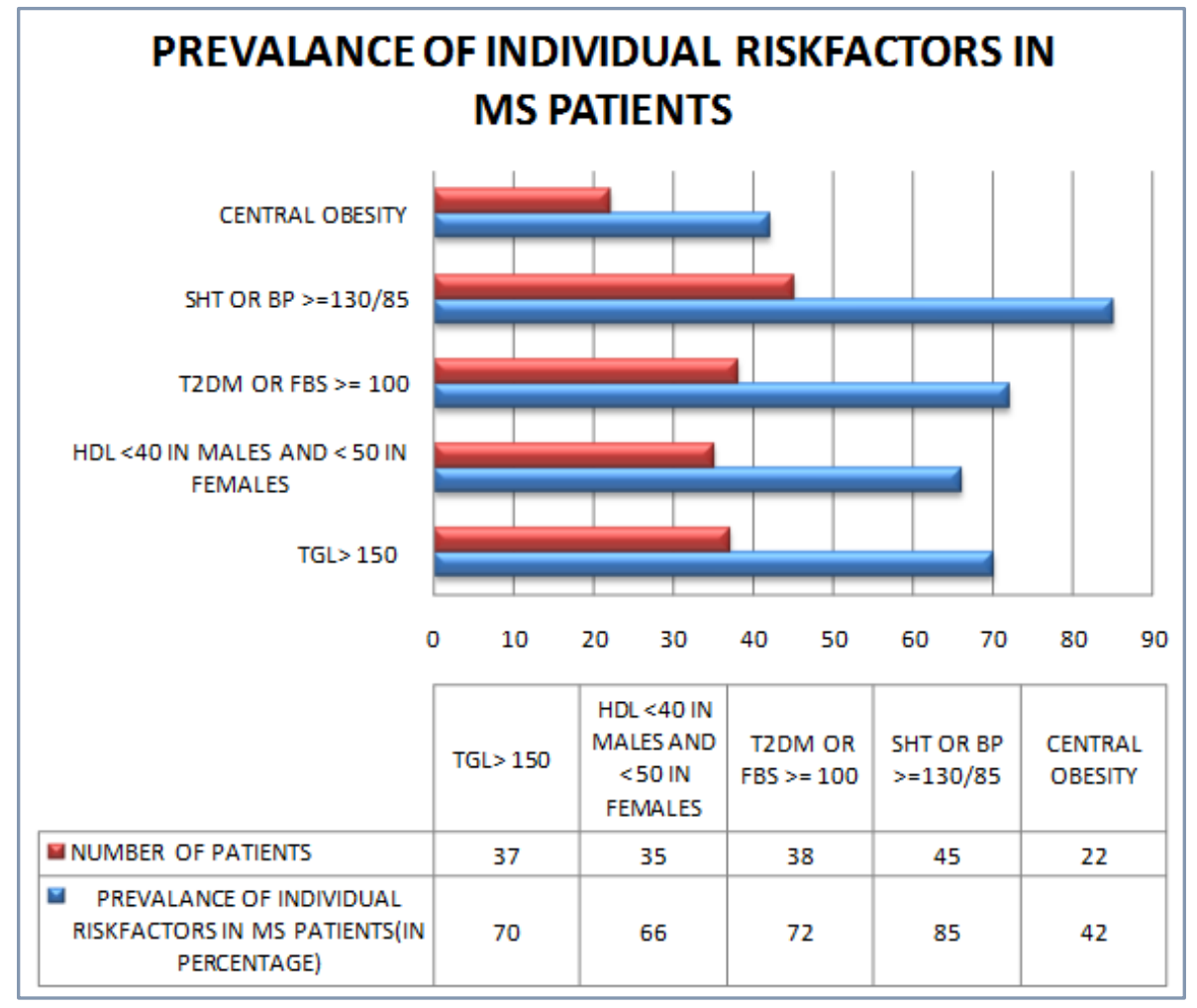

Fig. 2

\begin{tabular}{|c|c|c|}
\hline & $\begin{array}{c}\text { PREVALANCE OF INDIVIDUAL } \\
\text { RISKFACTORS } \\
\text { IN MS PATIENTS } \\
\text { (IN PERCENTAGE) }\end{array}$ & $\begin{array}{c}\text { NUMBER OF } \\
\text { PATIENTS }\end{array}$ \\
\hline TGL> 150 & $70 \%$ & 37 \\
\hline HDL <40 IN MALES AND < 50 & $66 \%$ & 35 \\
\hline IN FEMALES & $72 \%$ & 38 \\
\hline T2DM OR FBS > = 100 & $85 \%$ & 45 \\
\hline SHT OR BP > $130 / 85$ & $42 \%$ & 22 \\
\hline CENTRAL OBESITY & Table 2: Prevalance of Individual Risk Factors in MS Patients \\
\hline
\end{tabular}




\section{AGE DISTRIBUTION IN CAD PATIENTS}

(Figure 3, Table 3)

In this study, it is observed that the number of coronary Artery disease patients increase as the age advances. But no statistical significance $(p-$ value $=0.279$ ) was noted between the various age groups with metabolic syndrome when compared to those without metabolic syndrome.

The mean age of an Asian Indian patient suffering a myocardial infarction is only 50 years. $25 \%$ of all MIs in this population occur under the age of 40 years. This observation is supported by studies of Sumita et al. ${ }^{31}$ John E. Morley et al. ${ }^{32}$ and Melissari et al. ${ }^{33}$ Pandey et al. ${ }^{34}$ which showed the greater incidence of coronary artery disease with advancing age.

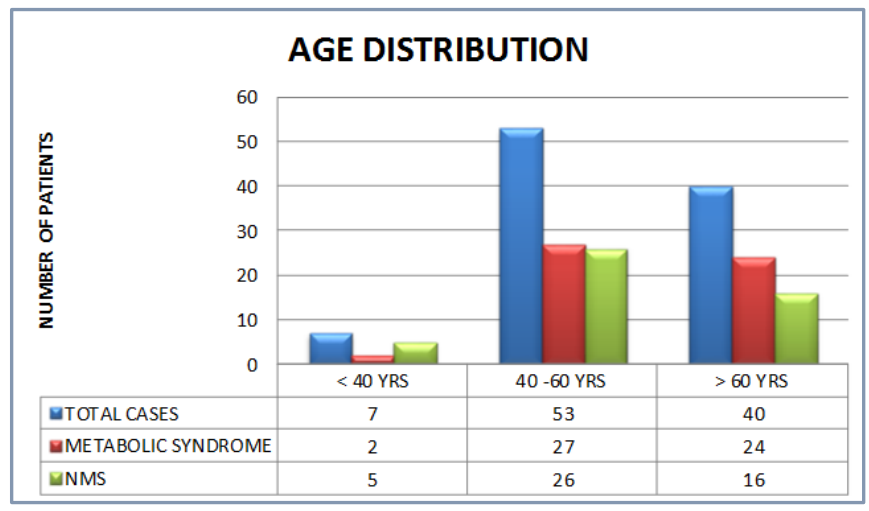

Fig.3

\begin{tabular}{|ll|r|r|r|r|}
\hline & & \multicolumn{2}{|c|}{ Age } & \multirow{2}{*}{ Total } \\
\cline { 2 - 5 } & $20-39$ & $40-59$ & $>60$ & 53 \\
\hline $\begin{array}{l}\text { Metabolic } \\
\text { syndrome }\end{array}$ & $\begin{array}{l}\text { Present } \text { Count } \\
\text { \% within Metabolic } \\
\end{array}$ & $3.8 \%$ & $50.9 \%$ & $45.3 \%$ & $100.0 \%$ \\
& $\begin{array}{l}\text { syndrome } \\
\text { Absent }\end{array}$ & & & & \\
\cline { 2 - 5 } & $\begin{array}{l}\text { Count } \\
\text { syndrome }\end{array}$ & $10.6 \%$ & $55.3 \%$ & $34.0 \%$ & $100.0 \%$ \\
\hline Total & $\begin{array}{l}\text { Count } \\
\text { \% within Metabolic } \\
\text { syndrome }\end{array}$ & $7.0 \%$ & $53.0 \%$ & $40.0 \%$ & $100.0 \%$ \\
\hline
\end{tabular}

Table 3: Age Distribution in CAD Patients

$(\mathrm{P}-\mathrm{VALUE}=\mathrm{NOT}$ SIGNIFICANT $)$

\section{SEX DISTRIBUTION IN CAD PATIENTS}

\section{(Figure 4, Table 4)}

The current study shows the males (70\%) show higher prevalence of coronary event than female (30\%) patients. Similarly in patients with metabolic syndrome higher prevalence were found in males (62.3\%) than females (37.7\%). Though there is no statistical significance to the sex distribution in terms of metabolic syndrome was noted ( $p$ value $=0.73$ ).

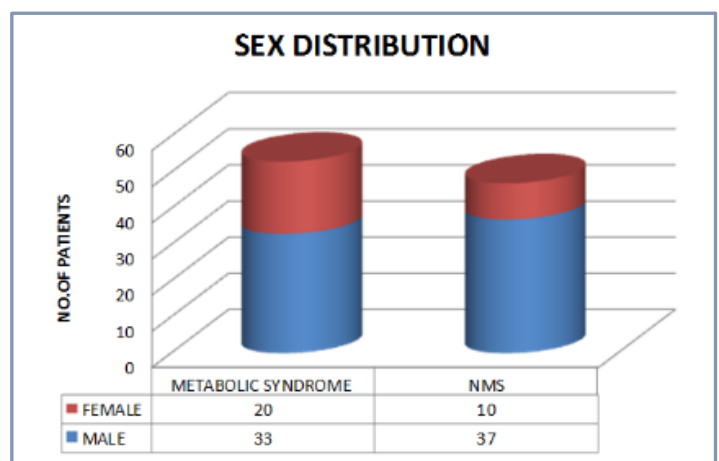

Fig. 4

\begin{tabular}{|c|c|c|c|c|c|}
\hline & & & \multicolumn{2}{|c|}{ Gender } & \multirow[b]{2}{*}{ Total } \\
\hline & & & Female & Male & \\
\hline \multirow[t]{2}{*}{ Metabolic syndrome } & Present & $\begin{array}{l}\text { Count } \\
\% \text { within Metabolic } \\
\text { syndrome }\end{array}$ & $\begin{array}{r}20 \\
37.7 \%\end{array}$ & $\begin{array}{r}33 \\
62.3 \%\end{array}$ & $\begin{array}{r}53 \\
100.0 \%\end{array}$ \\
\hline & Absent & $\begin{array}{l}\text { Count } \\
\% \text { within Metabolic } \\
\text { syndrome }\end{array}$ & $\begin{array}{r}10 \\
21.3 \%\end{array}$ & $\begin{array}{r}37 \\
78.7 \%\end{array}$ & $\begin{array}{r}47 \\
100.0 \%\end{array}$ \\
\hline Total & & $\begin{array}{l}\text { Count } \\
\% \text { within Metabolic } \\
\text { syndrome }\end{array}$ & $\begin{array}{r}30 \\
30.0 \%\end{array}$ & $\begin{array}{r}70 \\
70.0 \%\end{array}$ & $\begin{array}{r}100 \\
100.0 \%\end{array}$ \\
\hline
\end{tabular}

Table 4: Sex Distribution in CAD Patients

$(\mathrm{P}-\mathrm{VALUE}=$ NOT SIGNIFICANT $)$ 
PREVALENCE OF METABOLIC SYNDROME IN DIABETIC \& NON DIABETIC:

(Figure 5, 6, Table 5) In the study population 32\% were diabetic and the prevalence of metabolic syndrome among those diabetes was $72 \%$ (Figure 5,6 ). This clearly shows the higher prevalence of metabolic syndrome among diabetics. There is clear association between metabolic syndrome and diabetes which is statistically significant $(\mathrm{p}=0.001)$. Which has also been reported by Benghazi et al. ${ }^{35}$

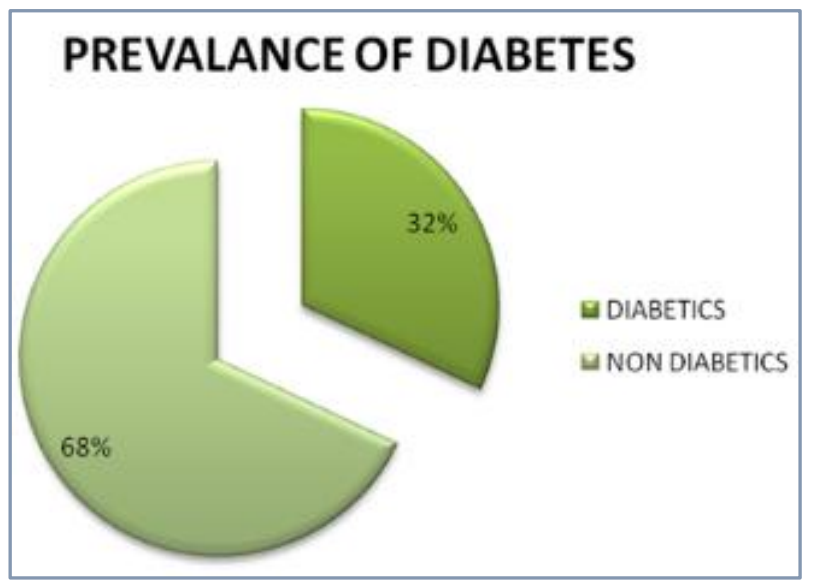

Fig. 5

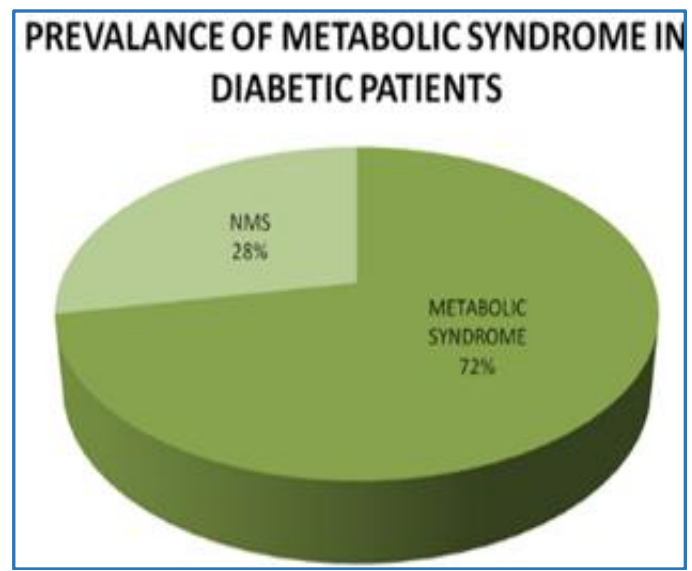

Fig. 6

\begin{tabular}{|c|c|c|c|c|c|}
\hline & \multicolumn{2}{|c|}{ DM } & \multirow[b]{2}{*}{ Total } \\
\hline & & & Yes & No & \\
\hline \multirow{6}{*}{$\begin{array}{l}\text { Metabolic } \\
\text { yndrome }\end{array}$} & Present & Count & 23 & 30 & 53 \\
\hline & & $\begin{array}{l}\text { \% within Metabolic } \\
\text { syndrome }\end{array}$ & $43.4 \%$ & $56.6 \%$ & 100.09 \\
\hline & Absent & Count & 9 & 38 & 47 \\
\hline & & $\begin{array}{l}\text { \% within Metabolic } \\
\text { syndrome }\end{array}$ & $19.1 \%$ & $80.9 \%$ & $100.0 \%$ \\
\hline & & Count & 32 & 68 & 100 \\
\hline & & $\begin{array}{l}\text { \% with Metabolic } \\
\text { syndrome }\end{array}$ & $72 \%$ & $28 \%$ & $100.09 \mathrm{~A}$ \\
\hline
\end{tabular}

Table 5: Metabolic syndrome VS DM

$(\mathrm{P}-$ VALUE SIGNIFICANT $=0.001)$

PREVALENCE OF METABOLIC SYNDROME IN HYPERTENSIVE AND NON HYPERTENSIVES:

(Figure 7, 8) (Table 6): The study shows prevalence of hypertension being $34 \%$ (Figure 7,8 ) and a clear higher prevalence of metabolic syndrome among hypertensive (74\%). There is a clear association between metabolic syndrome and hypertension as shown statistically ( $\mathrm{p}$-value $=0.003$ ), which has also been reported by Kjeldson et al. ${ }^{36}$

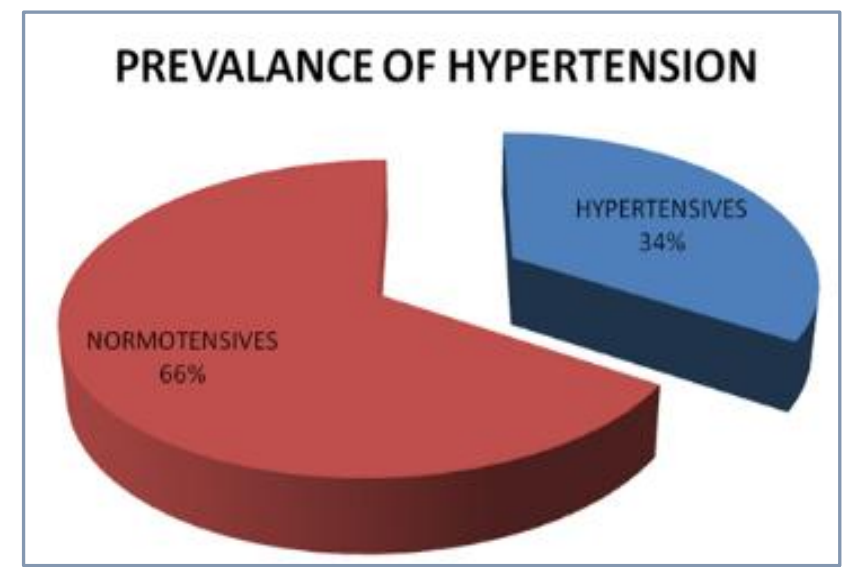

Fig. 7

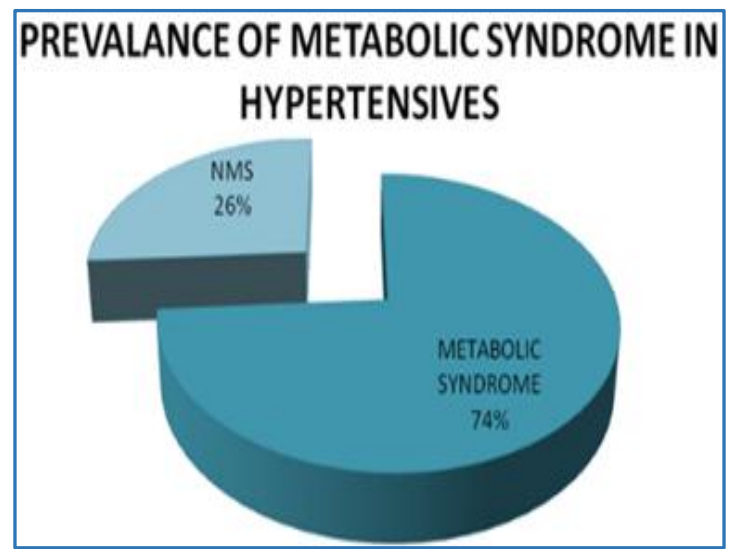

Fig. 8 


\begin{tabular}{|ll|r|r|r|}
\hline & & \multicolumn{2}{|c|}{ SHT } & \multirow{2}{*}{ Total } \\
\cline { 2 - 4 } & \multicolumn{1}{|c|}{ Yes } & \multicolumn{1}{c|}{ No } & \multicolumn{1}{c|}{53} \\
Metabolic & Present & Count & 28 & \\
& \% within Metabolic & $47.2 \%$ & $52.8 \%$ & $100.0 \%$ \\
& $\quad$ syndrome & & & \\
\cline { 2 - 4 } & Absent & Count & 38 & 47 \\
& \% within Metabolic & $19.1 \%$ & $80.9 \%$ & $100.0 \%$ \\
& syndrome & 34 & 66 & 100 \\
& $\begin{array}{l}\text { Count } \\
\text { \% within Metabolic } \\
\text { syndrome }\end{array}$ & $74 \%$ & $26 \%$ & $100.0 \%$ \\
\hline
\end{tabular}

Table 6: Metabolic syndrome VS SHT

$(\mathrm{P}-$ VALUE SIGNIFICANT $=0.003)$

\section{PREVALENCE OF METABOLIC SYNDROME IN SMOKERS:}

(Figure 9, 10). (Table 7): The study shows the prevalence of smoking is $35 \%$ (Figure 8,9 ). The prevalence of metabolic syndrome in smokers is $46 \%$ compared with $54 \%$ with nonmetabolic syndrome. Thus no statistically association is found between metabolic syndrome and smoking ( $p$ value $=0.284$ )

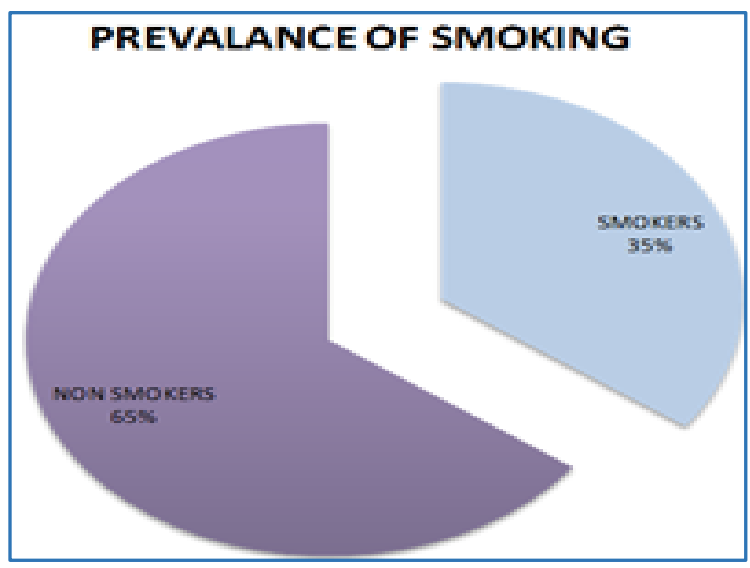

Fig. 9

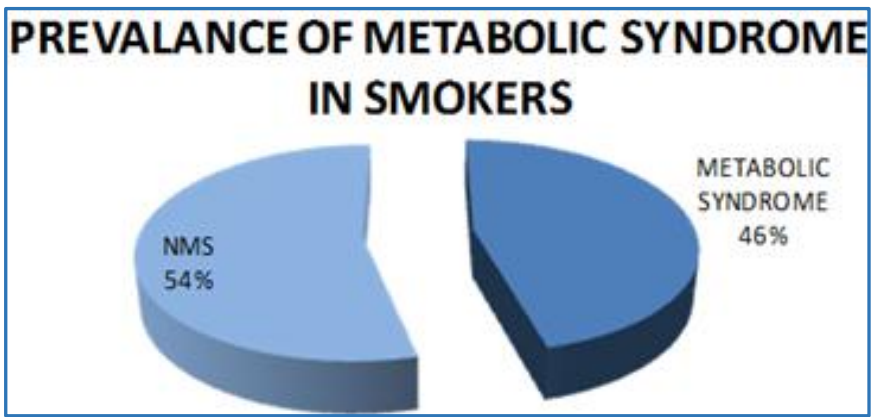

Fig. 10

\begin{tabular}{|c|c|c|c|c|c|}
\hline & & & Smo & & \\
\hline & & & Yes & No & Total \\
\hline Metabolic syndrome & Present & Count & 16 & 37 & 53 \\
\hline & & $\begin{array}{l}\% \text { within Metabolic } \\
\text { syndrome }\end{array}$ & $30.2 \%$ & $69.8 \%$ & $100.0 \%$ \\
\hline & Absent & Count & 19 & 28 & 47 \\
\hline & & $\begin{array}{l}\% \text { within Metabolic } \\
\text { syndrome }\end{array}$ & $40.4 \%$ & $59.6 \%$ & $100.0 \%$ \\
\hline Total & & Count & 35 & 65 & 100 \\
\hline
\end{tabular}

Table 7: Metabolic syndrome VS Smoking (P-VALUE =NOT SIGNIFICANT)

PREVALANCE OF METABOLIC SYNDROME AMONG ALCOHOLICS:

(Figure 11, 12) (Table 8): This study showed prevalence of alcohol consumption among $33 \%$ of study population. The prevalence of metabolic syndrome among the alcoholics is $39 \%$ (non-metabolic group 61\%). There is no statistical significance ( $p$-value=0.056) between alcoholism and metabolic syndrome in the background of acute myocardial infarction. Mathew Freiberg et al shows that mild to moderate alcohol consumption is associated with lower prevalence of MS with a favorable influence on lipids, waist circumference and fasting Insulin. ${ }^{37}$ 

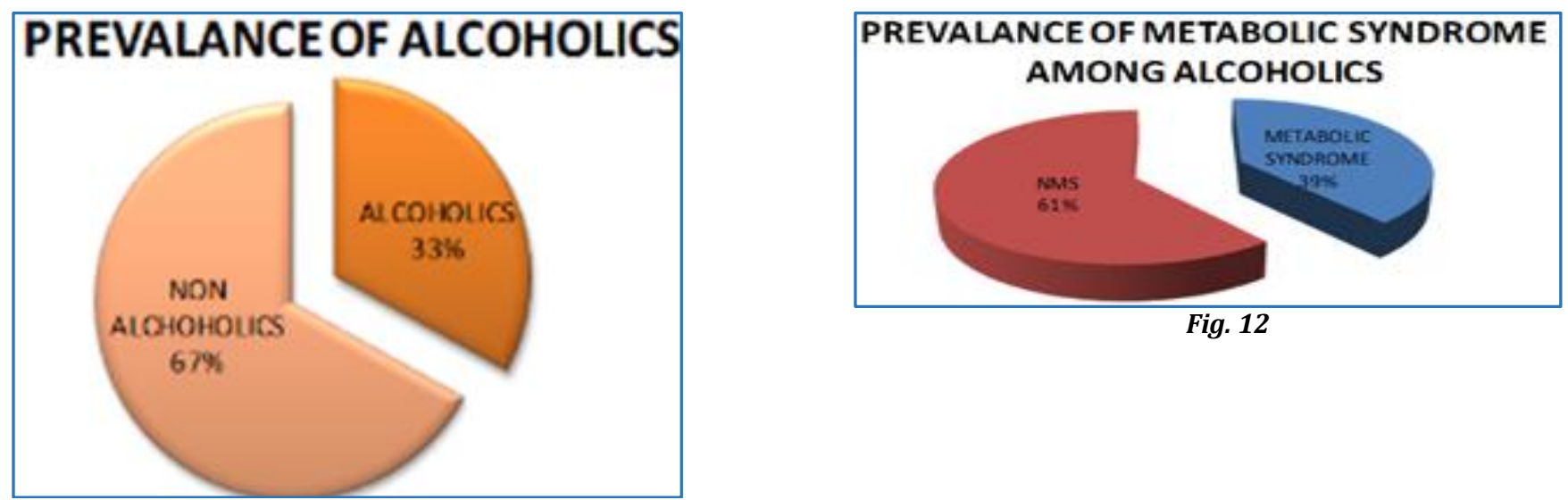

Fig. 12

Fig. 11

\begin{tabular}{|c|c|c|c|c|c|}
\hline & & & $\overline{\text { Alco }}$ & & \\
\hline & & & Yes & No & Total \\
\hline Metabolic syndrome & Present & Count & 13 & 40 & 53 \\
\hline & & $\begin{array}{l}\% \text { within Metabolic } \\
\text { syndrome }\end{array}$ & $24.5 \%$ & $75.5 \%$ & $100.0 \%$ \\
\hline & Absent & Count & 20 & 27 & 47 \\
\hline & & $\begin{array}{l}\% \text { within Metabolic } \\
\text { syndrome }\end{array}$ & $42.6 \%$ & $57.4 \%$ & $100.0 \%$ \\
\hline Total & & Count & 33 & 67 & 100 \\
\hline
\end{tabular}

Table 8: Metabolic syndrome VS Alcohol

$(\mathrm{P}-\mathrm{VALUE}=\mathrm{NOT}$ SIGNIFICANT)

PREVALANCE OF METABOLIC SYNDROME IN PATIENTS WITH POSITIVE FAMILY HISTORY:

(Figure 13, 14) (Table 9): The study showed less prevalence of positive family history $27 \%$ in the study population but a higher prevalence of metabolic syndrome $63 \%$ among those with positive family history, but no statistically significance was noted (pvalue $=0.225$ ).

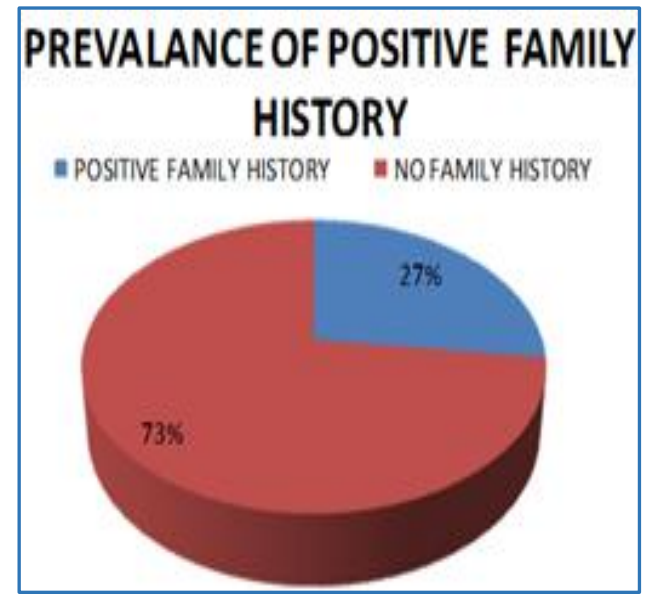

Fig. 13

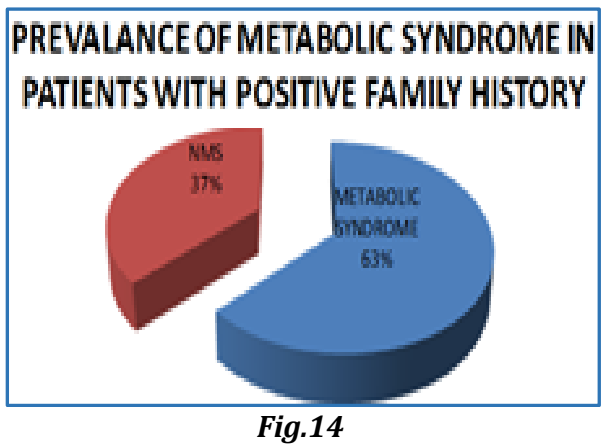




\begin{tabular}{|c|c|c|c|c|c|}
\hline & & & \multicolumn{2}{|c|}{ Family History } & \multirow[b]{2}{*}{ Total } \\
\hline & & & Yos & No & \\
\hline \multirow[t]{4}{*}{ Metabolic syndrome } & Present & Count & 17 & 36 & 53 \\
\hline & & $\begin{array}{l}\text { \% within Metabolic } \\
\text { syndrome }\end{array}$ & $32.1 \%$ & $67.9 \%$ & $100.0 \%$ \\
\hline & Absent & Count & 10 & 37 & 47 \\
\hline & & $\begin{array}{l}\% \text { within Metabolic } \\
\text { syndrome }\end{array}$ & $21.3 \%$ & $78.7 \%$ & $100.0 \%$ \\
\hline Total & & Count & 27 & 73 & 100 \\
\hline
\end{tabular}

Table 9: Metabolic syndrome VS Family History

$(\mathrm{P}-\mathrm{VALUE}=$ NOT SIGNIFICANT)

\section{ECG CHANGES IN STUDY POPULATION:}

(Figure15, 16) (Table 10, 11): Among 100 patients, 27\% had anterior wall mi changes; $33 \%$ had inferior wall mi changes; $24 \%$ had antero septal mi changes, $7 \%$ had extensive anterior wall mi changes, $9 \%$ had Inferior Wall/posterior wall mi changes.

Higher prevalence of metabolic syndrome was noted IWMI/PWMI 89\% followed by anterior wall myocardial infarction 78\%. Inferior wall $\mathrm{mi}$ and antero septal and extensive anterior wall changes were noted more in non-metabolic syndrome group.

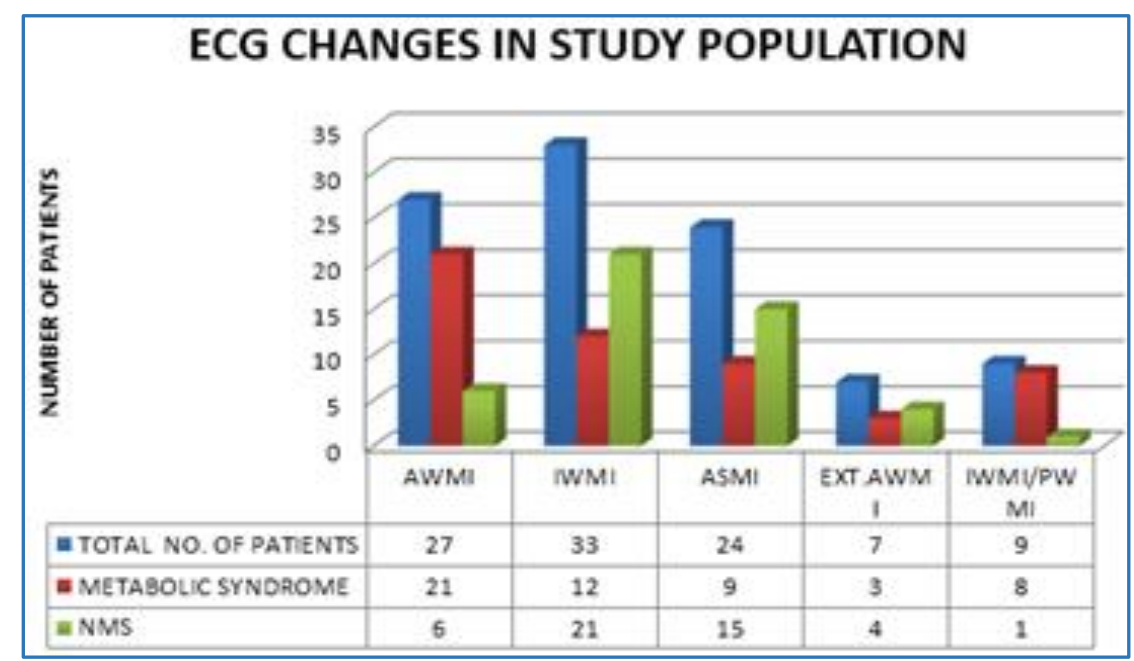

Fig. 15

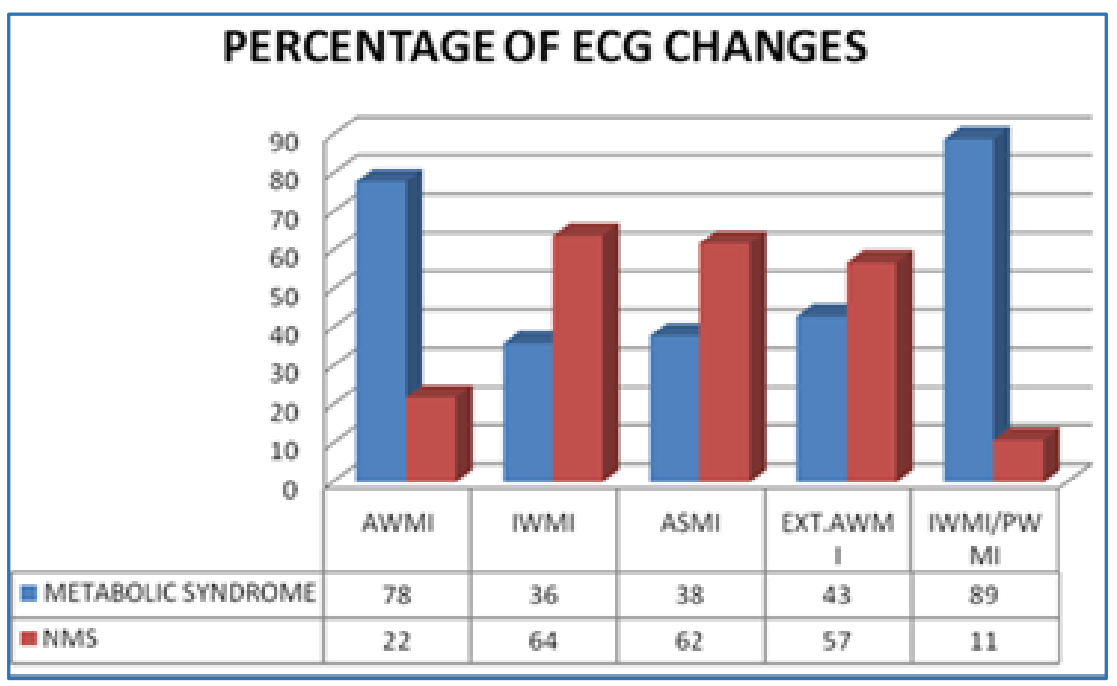

Fig. 16 


\begin{tabular}{|c|c|c|c|}
\hline & TOTAL NO. OF PATIENTS & METABOLIC SYNDROME & NMS \\
\hline AWMI & 27 & 21 & 6 \\
\hline IWMI & 33 & 12 & 21 \\
\hline ASMI & 24 & 9 & 15 \\
\hline EXT.AWMI & 7 & 3 & 4 \\
\hline IWMI/PWMI & 9 & 8 & 1 \\
\hline \multicolumn{3}{|c|}{ Table 10: Prevalence of AMI } \\
\hline
\end{tabular}

\begin{tabular}{|c|c|c|}
\hline & $\begin{array}{c}\text { METABOLIC } \\
\text { SYNDROME }\end{array}$ & NMS \\
\hline AWMI & $78 \%$ & $22 \%$ \\
\hline IWMI & $36 \%$ & $64 \%$ \\
\hline ASMI & $38 \%$ & $62 \%$ \\
\hline EXT.AWMI & $43 \%$ & $57 \%$ \\
\hline IWMI/PWMI & $89 \%$ & $11 \%$ \\
\hline \multicolumn{3}{|c|}{ Table 11: Percentage of Prevalence of AMI } \\
\hline
\end{tabular}

